\begin{tabular}{|c|c|c|}
\hline $\begin{array}{l}\text { An International Biannual Open Access } \\
\text { Peer-Reviewed/Refereed Journal } \\
\text { JOURNAL OF GLOBAL RESOURCES } \\
\text { Published by : ISDESR, Jaipur, India }\end{array}$ & 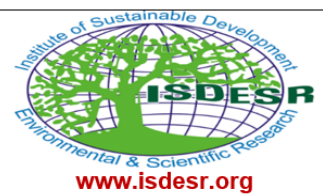 & $\begin{array}{r}\text { ISSN: } 2395-3160 \text { (Print) } \\
\text { ISSN: } 2455-2445 \text { (Online) } \\
\text { January 2022, Volume } 08 \text { (01) } \\
\text { DOI Prefix: } 10.46587 / \text { JGR }\end{array}$ \\
\hline
\end{tabular}

15

\title{
EXPEDITIOUS RESPONSE TO EPIDEMICS: THE CHRONICLE OF NIPAH IN KERALA
}

\author{
Ashique Vadakkuveettil ${ }^{1}$, Aakriti Grover ${ }^{2}$ and Rohini Menon ${ }^{3}$
}

${ }^{1}$ Research Scholar, ${ }^{2}$ Assistant Professor

Department of Geography, Central University of Tamil Nadu, Thiruvarur, Tamil Nadu, India.

${ }^{3}$ Research \& Documentation Officer, Environment, Technology and Community and Health (ETCH), Kalyan, Mumbai, India

Email: ashique.vv@outlook.com

How to cite this paper:

Vadakkuveettil, Ashique; Grover, Aakriti and Menon, Rohini (2022) Expeditious response to epidemics: The Chronicle of Nipah in Kerala, Journal of Global Resources, Vol. 08 (01)

DOI:

10.46587/JGR.2022.v08i01.015

Received: 12 Sep. 2021

Reviewed: 03 Nov. 2021

Revised: 16 Nov. 2021

Final Accepted: 02 Dec. 2021

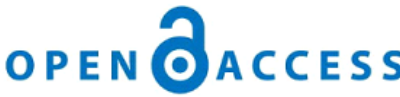

Freely available Online www.isdesr.org
Abstract: Kerala witnessed a catastrophic outbreak of the Nipah virus (NiV) in May 2018, with a fatality rate of 40-75 per cent. The Nipah virus is recognised by the World Health Organization (WHO) as a significant public health concern, and it's one among the priority diseases for accelerated $R \& D$ due to the severe lack of available countermeasures against it. There is no vaccine or cure for the infection. The state of Kerala showed an exemplary response to the outbreak. This involved rapid and effective dissemination of necessary precautions to the broader public. Internet social media played a crucial role in spreading these messages. Although the disease claimed 21 lives, it could have been a lot worse if the state had not taken the measures for proper mitigation. This work gives a brief overview of the Nipah virus, followed by a comprehensive outline of the Kerala outbreak. Community and individual responses to the Nipah outbreak have been analysed to illustrate how various groups and individuals, from health care and tourism departments to religious leaders, played a role in successfully eradicating the virus. Kerala's experience in containing epidemics is expected to become a reference point for other states and regions that may find similar situations.

Keywords: Community Response, Epidemic, Nipah Virus Infection (NiV). 


\section{Introduction}

According to the World Health Organization (WHO), Nipah Virus Infection (NiV) is a zoonotic virus (it is transmitted from animals to humans) and can also be transmitted through contaminated food or directly between people. Currently, there are no vaccines to prevent NiV (World Health Organization, 2018). The virus is a part of the genus Henipavirus and subfamily Paramyxoviridae. It is a highly pathogenic zoonotic disease that evolves, with outbreaks recorded from countries in South East Asia (Thomas et al., 2019). The first known outbreak of the Nipah virus was in Malaysia in 1998, the second outbreak was in Bangladesh in 2001. In the same year, the first outbreak in India was reported in Siliguri, West Bengal, later on in 2007 in Nadia, West Bengal (Lam and Chua, 2002; Chadha et al., 2006; Looi and Chua, 2007; Rahman and Chakraborty, 2012). Again, in India, Kerala witnessed the deadly Nipah outbreak in May 2018, claiming 21 lives out of 23 infected patients with a case fatality rate (CFR) of 88.9 per cent (deaths/laboratoryconfirmed cases, 16/18). From the second case itself, a doctor from Baby Memorial Hospital noticed some similarities with the death of case $1 \&$ case 2 . As a result, on May 18, they sent samples to the Manipal Centre for Virus Research (MCVR) in Manipal, Karnataka. Following confirmation of Nipah, the Department of Health and Family Welfare (Government of Kerala) adopted quick public health response measures, including patient isolation, infection prevention and control (IPC) and the use of personal protective equipment (PPE) (Sadanadan et al., 2018). Along with the government, the expeditious response of the people in Kerala was also a key in successfully containing the Nipah virus. This paper analyses the community response of people in the Kozhikode district who were severely affected during the outbreak. The main aim of this study is to understand the evolution and changes in attitudes, knowledge, and behaviours of people in response to the Nipah outbreak.

\section{Study Area and Methodology}

This study has been carried out in the Kozhikode district as the first case of Nipah was reported here (Fig. 1). Kozhikode is one of the coastal districts of Kerala where Vasco Da Gama, the leader of a trade mission from Portugal, first landed in May 1498 (Ministry of Water Resources, 2013). The district covers an area of $2344 \mathrm{~km}^{2}$ and is well-connected by road, rail, and air. The Kannur district borders it to the north, the Wayanad district to the east, the Malappuram district to the south, and the Lakshadweep Sea to the west. It lies between the longitudes of $11^{\circ} 08^{\prime}$ ' and $11^{\circ} 50^{\prime}$ in the north and $75^{\circ} 30^{\prime}$ and $76^{\circ} 8^{\prime}$ in the east (Department of Mining and Geology, 2016). The participants of this research hail from various regions throughout the Kozhikode district, aged between 18-58. Online surveys have been done with the help of google forms to monitor the community response of people. All the information in this paper is based on the data collected from 100 respondents who took part in the online survey. Selected respondents were interviewed again personally or on call to share their experience of Nipah. Questions were asked to understand people's perceptions about Nipah and to analyse their behavioural change during and after one month of the Nipah outbreak. Finally, percentages were calculated, and graphs were constructed from the data using OriginPro 2021.

\section{Findings and Discussion}

Out of 100 respondents, 76 per cent were males, and 24 per cent were females. Around 63 per cent of the respondents were between the age of 18-28, and the remaining 37 per cent were between 29-58. Maximum number of people have a graduate degree $(51.1 \%)$ and a postgraduate degree (36\%). Respondents were the inhabitants of Mukkam, Nadapuram, Vanimal, Thuneri, Changaroth, Koduvally, etc. Case 1 was reported from a place named Sooppikkada in Changaroth village. Most of the patients were the inhabitants of infected areas or had close contact with the infected persons. In the initial stage, Nipah was not confirmed; hence, the patients 
had close contact with people in and around hospitals (Fig. 1). Most cases are transmitted either from the hospital or from the patient's home. Once it was confirmed as Nipah, the government took immediate actions like asking schools and other educational institutions to remain closed, implementing travel bans, distributing awareness notices to all government and private institutions, pasting posters in public places and other public gathering places like hospitals, mosques, etc. Awareness was given to people from mosques regarding the safety measures as these areas were Muslim majority regions, and most of them gathered in the mosques on Friday.

\section{Figure 01: Study area}

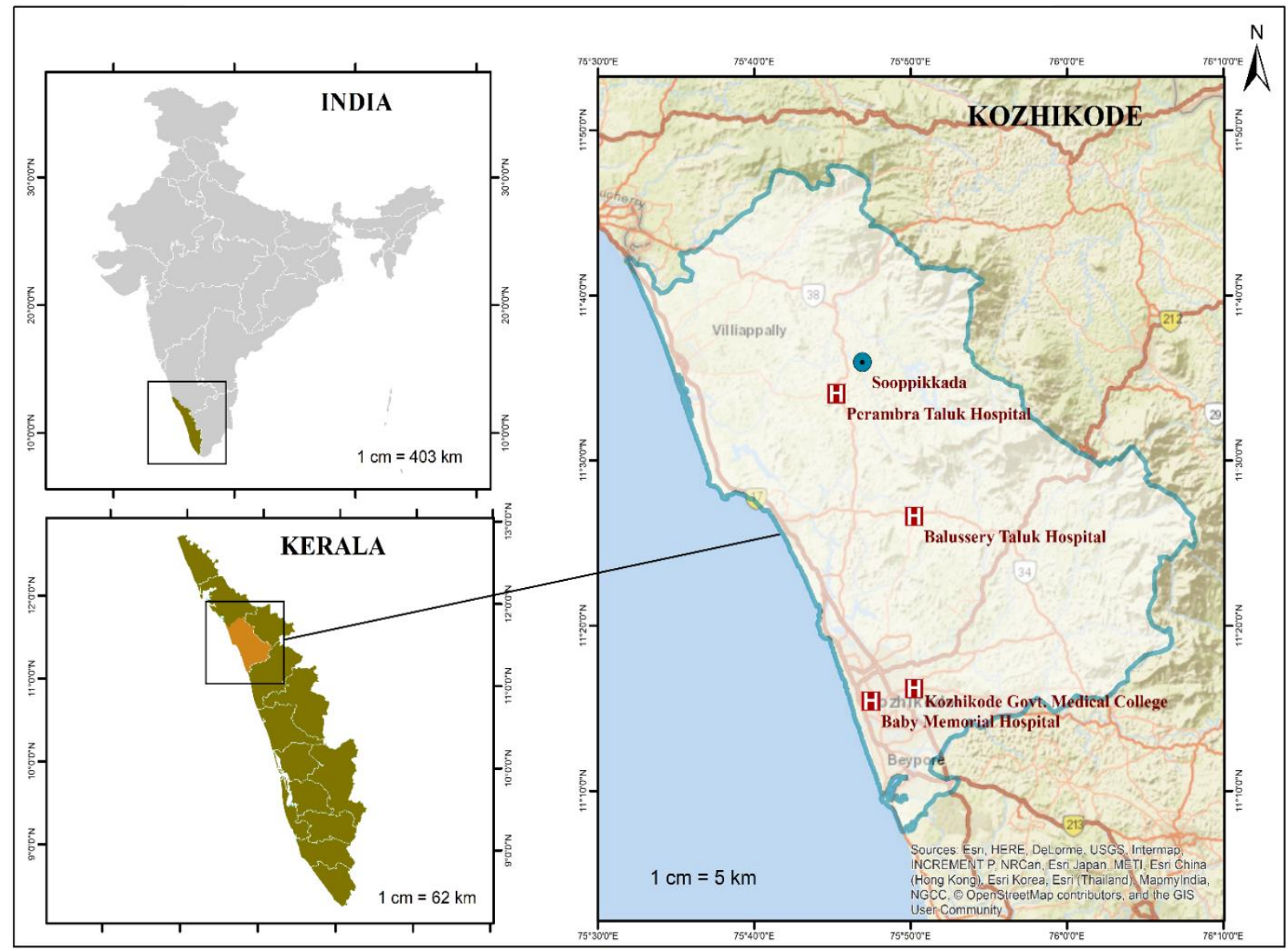

Initially, most of the people received information about Nipah through social media (43\%), newspapers (25\%) and T.V/Radio (18\%). At the same time, some of them (14\%) get to know about it from their friends or relatives (Fig. 2). This shows the role of social media in the present era for disaster mitigation. It is to consider that Kerala's high literacy rate helped people be more aware of the outbreak. The lifestyle of people had a very noticeable change at this time. Many of the people (43\%) rarely went outside during the outbreak time while not many of them (6\%) never went outside. Majority of people (47\%) went outside to an average extent, and very few people $(4 \%)$ went outside frequently. Some of them even continued to remain cautious even after being free from the disease (Fig. 3). As the fruit-eating bats caused Nipah, most people avoided buying fruits during that time, but later, when the state was free from Nipah, people started buying it again (Fig. 4a). However, most of them avoided eating bird or animal bitten fruits during and after Nipah (Fig. 4b). Needless to mention, it affected the daily life of the people. Shops, restaurants, buses, public places, hospitals etc., remained empty during those days as people were being very alert and cautious to avoid visiting infected areas particularly, and crowded places in general (Fig. 5). Many people preferred to cancel their travel plans and other public events out of the fear of getting infected (Fig. 6). 


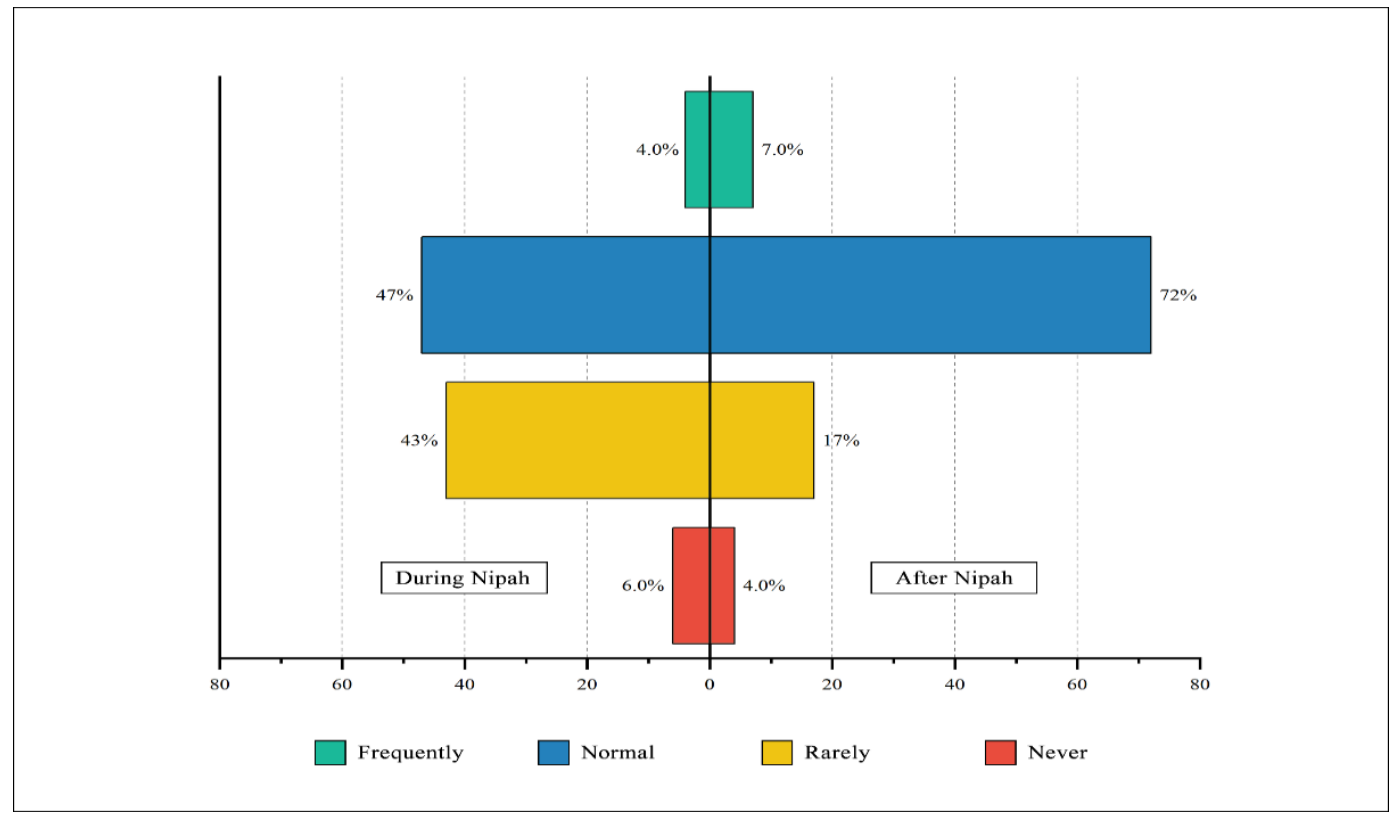

People preferred travelling in private vehicles rather than public transport. A complete transition has been taking place in people's lifestyles, illustrating how terrified people were in those days. Most of them (93\%) kept checking Nipah updates regularly because of its severity (Fig. 7). When the virus got cured, and patients became free from it entirely, the majority of people believed that this disease was curable (64\%). However, most individuals were aware of how deadly this virus was (71\%) (Fig. 7). It took plenty of time for the people of Kerala to restart their lives normally, even after Nipah was cured. Many of them remained fearful of the next outbreak.

Figure 03: Public Response

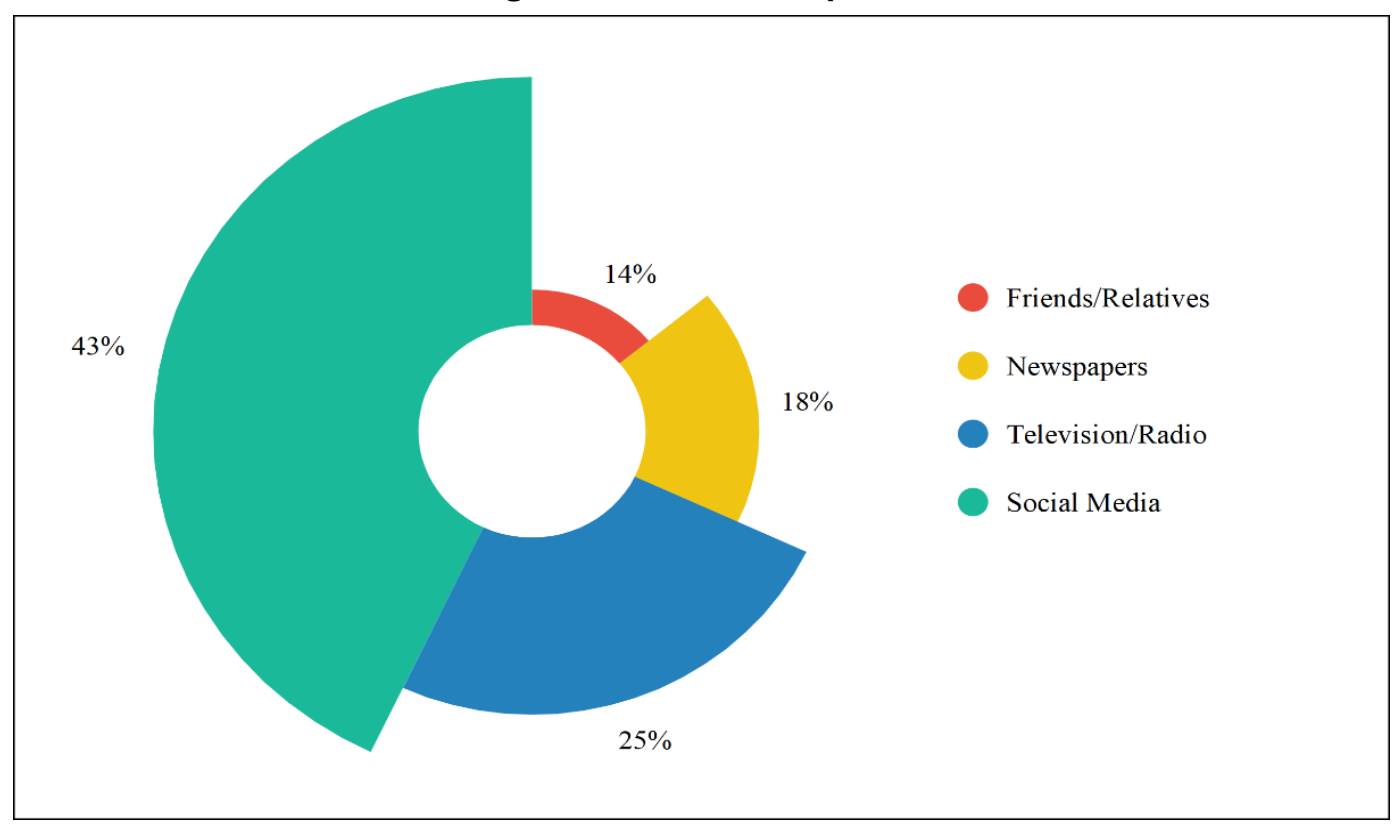


Figure 04: Frequency of people went out during and after Nipah

a)
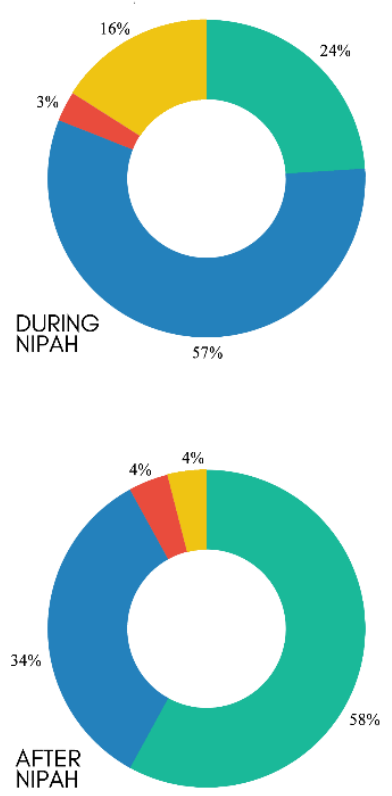

Never b)

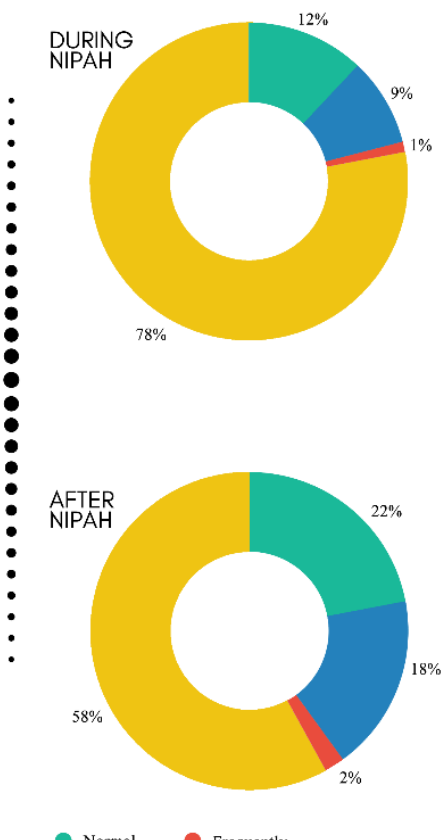

Normal Frequently

Figure 05: Alertness towards visiting places (in \%)

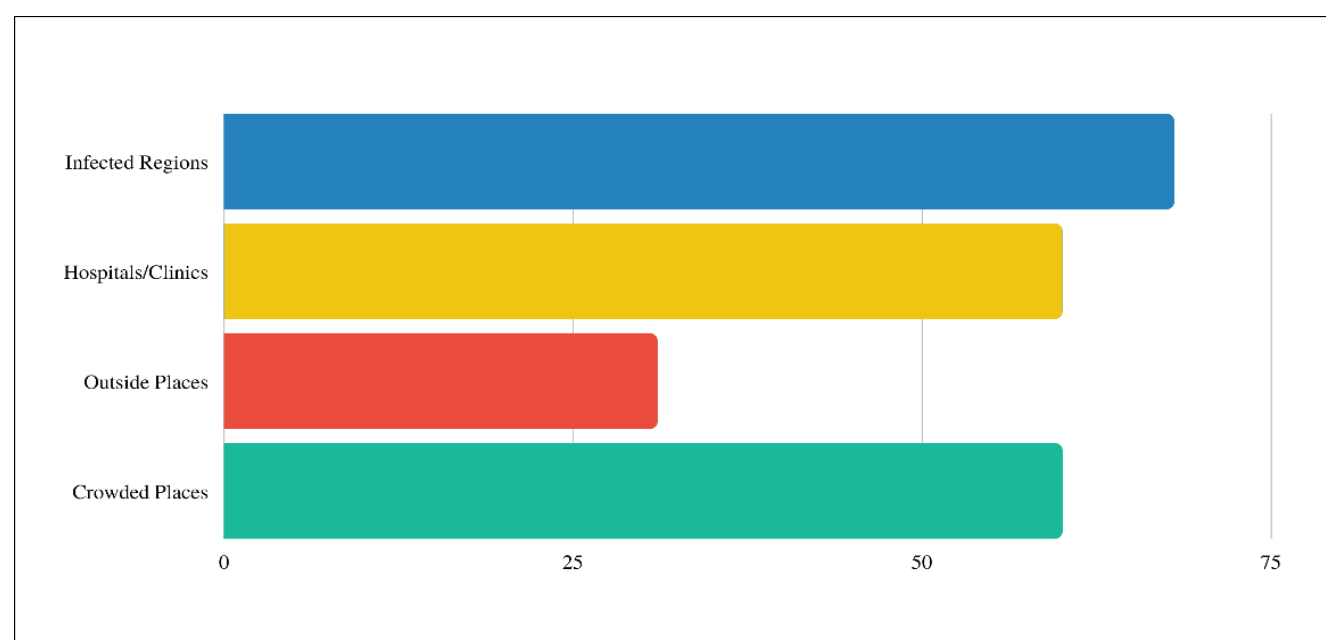

Figure 06: Response to travel plan and public gathering (in \%)

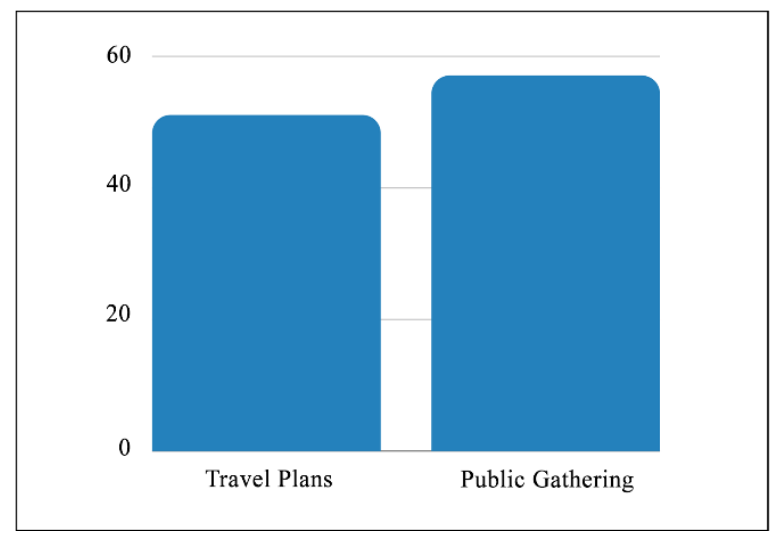

Figure 07: People's perception on awareness and severity of Nipah (in \%)

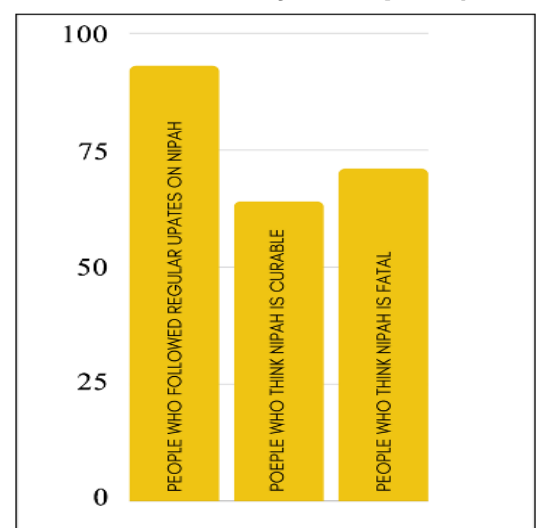




\section{Conclusion}

The deadly zoonotic Nipah Virus, which put the state of Kerala to a standstill, has shown the immense sensible precautions taken by the people. The outbreak of the virus made people aware of their surroundings and cognizant of how to handle such situations with a comparatively low death toll due to the highly positive response to the disease. Social media played a vital role in spreading awareness about the virus, which indeed had a significant role in response and precautions taken by them, which helped to cease the spread of the virus to the massive group of people. The government also immediately shut down the institutions, distributed Nipah virus awareness notices, advised less human contact with the infected and requested to avoid crowded places, etc. Concerning all this, the people's lives were adversely affected, but after the state came out clean, everyone continued with their daily life. Nevertheless, this disease left a negative impact as well. The fear of getting infected made people a little less of a human in treating the people who had the virus or the people belonging to the infected area. The fear made them treat these people indifferently even after the cure. The previous carrier of the virus and their families faced isolation and an undeclared social boycott. To resolve this maltreatment towards such victims and their families, a few doctors themselves came in direct physical contact with them. They talked about how unacceptable and unnecessary it is to give such treatment to them. By taking care of the infected patients by this deadly virus, the government and health officials showed great bravery. Not to mention the sacrifice of the nurse named Lini Puthussery, who got infected and lost her life during the service. She set an example of humanity, empathy and compassion in the society. The immediate efforts taken by the government and health officials during the Nipah virus outbreak in Kerala were acknowledged and appreciated in different parts of the world.

Acknowledgements: We would like to thank all of our respondents for their time in helping us complete our survey. We are also thankful to Monib Ahmad, Salih Madathil and Aisha Wani for their kind support and assistance.

\section{References}

1. Chadha, M. S. et al. (2006). 'Nipah virus-associated encephalitis outbreak, Siliguri, India.', Emerging infectious diseases, 12(2), pp. 235-240. doi: 10.3201/eid1202.051247.

2. Department of Mining and Geology (2016). 'DISTRICT SURVEY REPORT OF MINOR MINERALS'.

3. Lam, S. K. and Chua, K. B. (2002) 'Nipah Virus Encephalitis Outbreak in Malaysia', Clinical Infectious Diseases, 34(Supplement_2), pp. S48-S51. doi: 10.1086/338818.

4. Looi, L.-M. and Chua, K.-B. (2007). 'Lessons from the Nipah virus outbreak in Malaysia.', The Malaysian journal of pathology, 29(2), pp. 63-67.

5. Rahman, M. and Chakraborty, A. (2012). 'Nipah virus outbreaks in Bangladesh: a deadly infectious disease.', WHO South-East Asia journal of public health, 1(2), pp. 208-212. doi: 10.4103/22243151.206933.

6. Ravi, A. (2013) Ground Water Information Booklet of Kozhikode District, Kerala.

7. Sadanadan, R. et al. (2018). 'Towards global health security: response to the May 2018 Nipah virus outbreak linked to Pteropus bats in Kerala, India', BMJ global health, 3(6), pp. e001086-e001086. doi: 10.1136/bmjgh-2018-001086.

8. Thomas, B. et al. (2019). 'Nipah Virus Infection in Kozhikode, Kerala, South India, in 2018: Epidemiology of an Outbreak of an Emerging Disease.', Indian journal of community medicine : official publication of Indian Association of Preventive \& Social Medicine, 44(4), pp. 383-387. doi: 10.4103/ijcm.IJCM_198_19.

9. World Health Organization (2018). Nipah virus Infection. Available at: https://www.who.int/healthtopics/nipah-virus-infection\#tab=tab_1 (Accessed: 2 January 2019). 